Економічні науки: збірник наукових праць Луцького національного технічного університету. Серія "Регіональна економіка". Випуск 18 (71). Редкол.: відп. ред. д.е.н., професор Л.Л. Ковальська. Луиьк: ІВВ Луиького НТУ, 2021. 278 с.

УДК 338.48

Матвійчук Л.Ю., д.е.н., професор,

Луцький національний технічний університет

Чепурда Л.М., д.е.н., професор,

Черкаський державний технологічний університет

\title{
РЕГІОНАЛЬНІ АСПЕКТИ ЗАБЕЗПЕЧЕННЯ ЯКОСТІ ПРОДУКЦІї ТА ПОСЛУГ ІНДУСТРІЇ ГОСТИННОСТІ
}

У статті визначено та систематизовано основні показники якості продукції та послуг індустрії гостинності в регіонах України. Доведено що одним 3 основних показників якості $є$ туристичний збір. Проведено аналіз обсягів туристичного збору в регіонах України. На прикладі міста Луцьк охарактеризовано основні регіональні продукти та послуги індустрії гостинності, Визначено напрями підвищення рівня їх якості території дослідження.

Ключові слова: якість продукції та послуг, регіон, туристичний збір, індустрія гостинності.

\section{Matviichuk L., Chepurda L. \\ REGIONAL ASPECTS OF QUALITY ASSURANCE OF PRODUCTS AND SERVICES OF THE HOSPITALITY INDUSTRY}

The article identifies and systematizes the main indicators of quality of products and services of the hospitality industry in the regions of Ukraine. The essence of the category «quality of products and services of the hospitality industry» is generalized and defined as an economic category that is measurably majestic and reflects the degree of satisfaction of consumer needs in the form of comprehensive tourism services provided by hospitality industry entities. It is determined that the quality of products and services of the hospitality industry in the regions is characterized by such indicators as the number of tourists, the money they spent during the trip, leisure time, as well as the range of services offered.

It has been proven that one of the main indicators of quality is the tourist tax levied on tourists by local authorities in order to invest in the development of the hospitality industry in the region (restoration or revitalization of monuments, infrastructure development, landscaping, events, etc.). Tourist tax is paid by tourists and guests of the region who come to the city or region for recreation. Analysis of the volume of tourist tax in the regions of Ukraine showed that the total amount of revenues to local budgets in 2020 amounted to about 130 million UAH, which is 
Економічні науки: збірник наукових праць Луцького національного технічного університету. Серія "Регіональна економіка". Випуск 18 (71). Редкол.: відп. ред. д.е.н., професор Л.Л. Ковальська. Луцьк: ІВВ Луцького НТУ, 2021. 278 с.

34\% less than in 2019. The leaders in this indicator in 2020 are Luhansk, Mykolaiv and Kyiv regions.

The state of the hospitality industry in Lutsk is analyzed. The analysis showed an increase in tourist fees in the city until 2019. The main regional products and services of the hospitality industry are described on the example of the city of Lutsk. To substantiate the feasibility of forming new proposals for products and services of the hospitality industry that meet international standards and find effective ways to improve the quality of the studied processes, we will conduct a SWOT-analysis of the development of the hospitality industry in the city. The conducted analysis showed sufficient resource potential in the city for the formation and provision of products and services of the hospitality industry of high quality.

The directions of increase of the level of their quality of the research territory are determined. It is proposed to increase the level of quality of products and services of the hospitality industry of the city of Lutsk by; formation of new tourist offers that would meet modern norms, rules and quality standards. increasing the level of promotion of the tourist potential of the city; increasing the number of tourist information centers in the city, as well as the introduction of regional organizations for the management of the tourist destination «Lutsk». industry.

Key words: quality of products and services, region, tourist tax, hospitality

Матвийчук Л.Ю., Чепурда Л.М.

\section{РЕГИОНАЛЬНЫЕ АСПЕКТЫ ОБЕСПЕЧЕНИЯ КАЧЕСТВА ПРОДУКЦИИ И УСЛУГ ИНДУСТРИИ ГОСТЕПРИИМСТВА}

В статье определены и систематизированы основные показатели качества продукции и услуг индустрии гостеприимства в регионах Украины. Доказано, что одним из основных показателей качества является туристический сбор. Проведен анализ объемов туристического сбора в регионах Украины. На примере города Луцк охарактеризованы основные региональные продукты и услуги индустрии гостеприимства. Определены направления повышения уровня их качества на территории исследования.

Ключевые слова: качество продукции и услуг, регион, туристический сбор, индустрия гостеприимства.

Постановка проблеми у загальному вигляді та ії зв'язок 3 важливими науковими та практичними завданнями. Сучасний рівень якості продукції та послуг індустрії гостинності, в регіонах України зумовлений значною кількістю факторів, серед яких визначальними $\epsilon$ економічні, політичні, природні, соціальні, безпекові (поширення пандемії «COVID-19») тощо. Тенденції, які відбуваються в Україні та 
Економічні науки: збірник наукових праць Луцького національного технічного університету. Серія "Регіональна економіка". Випуск 18 (71). Редкол.: відп. ред. д.е.н., професор Л.Л. Ковальська. Луиьк: ІВВ Луиького НТУ, 2021. 278 с.

світі за останні роки, найбільшою мірою вплинули на індустрію гостинності. Якість продукції та послуг індустрії гостинності в регіонах України можна проаналізувати за показниками туристичного збору. Можна припустити, що відносно високі показники туристичного збору свідчать про зацікавленість туристів місцевими локаціями та відносну задоволеність якістю наданих послуг та спожитих продуктів. Крім того, періодично 3'являються сучасні тренди в індустрії гостинності (новітні інформаційно-комунікаційні технології, електронна торгівля тощо), які визначають конкурентні переваги суб'єктів господарювання в регіоні та задають напрям розвитку індустрії гостинності регіону. Такі процеси зумовлюють пошук оптимальних шляхів підвищення якості продукції та послуг індустрії гостинності в регіонах, формування туристичної інфраструктури територій відповідно до міжнародних стандартів та кращих світових практик.

Аналіз останніх досліджень, у яких започатковано вирішення проблеми. Грунтовні наукові результати в дослідженні питань забезпечення якості продукції та послуг індустрії гостинності туристичних територій отримані такими вченими: О. Бандирською, Г. Бедрадіновою, В. Кифяком, Н. Кудлою, М. Мальською, С. Нездойміновим, В. Паппом, О. Решетняком, Т. Ткаченко, Л. Чепурдою та іншими. Серед зарубіжних вчених, що займалися підвищенням рівня якості надання туристичних послуг слід виділити, праці Д. Гарвіна, Дж. Джурана, А. Зоріна, В. Квартального, Дж. Харрингтона та інших. Водночас процеси підвищення якості продукції та послуг на рівні регіону не стали об'єктом системних досліджень, а тому потребують подальших досліджень.

Цілі статті. Метою дослідження є наукове обгрунтування можливих шляхів підвищення якості продукції та послуг індустрії гостинності в регіонах України на основі аналізу обсягів туристичного збору, а також формування пропозицій щодо підвищення рівня якості досліджуваних процесів індустрії гостинності міста Луцьк. 
Економічні науки: збірник наукових праць Луцького національного технічного університету. Серія "Регіональна економіка". Випуск 18 (71). Редкол.: відп. ред. д.е.н., професор Л.Л. Ковальська. Луиьк: ІВВ Луиького НТУ, 2021. 278 с.

\section{Виклад основного матеріалу дослідження 3 повним} обгрунтуванням отриманих наукових результатів. Якість $\epsilon$ одним з основним інструментів, що формує попит та асортимент пропозиції на ринку туристичних послуг регіонів. Якість сприяє поліпшенню конкурентних переваг регіонів України та окремих громад. Зазначене зумовлено доцільністю проведення аналізу якості продукції та послуг базуючись на показниках туристичного збору та пошуку пропозиції адаптації наявних регіональних туристичних продуктів до сучасних вимог та потреб туристів, що змінюються відповідно до умов часу.

Соціально-економічний розвиток регіонів потребує змін не тільки в структурі виробництва продукції та послуг індустрії гостинності, а й суттєвих змін в організації їх виробництва, просування та споживання. Зазначене вимагає наукового обгрунтування теоретичних положень і методологічних підходів підвищення якості продукції та послуг регіонів України [2].

Підходи вчених до застосування економічних засад формування якісних продукції та послуг на рівні регіону вимагають чіткого визначення категоріального апарату, що грунтується на великій кількості наукових досліджень 3 економіки туризму, регіональної економіки, рекреаційної географії тощо. Аналізуючи підходи вчених до категорії «якість продукції та послуг», можна дійти висновку, що якість є однією зі складних понять. Багатозначність трактувань такої дефініції визначається тим, що під терміном «якість» розуміється велика кількість специфічних властивостей предметів і явищ. Так, термін «якість», згідно з ДСТУ ISO 9000:2009 [10], означає ступінь, до якого сукупність власних характеристик задовольняє вимоги. Стандарт ДСТУ 2925-94 «Якість продукції. Оцінювання якості. Терміни та визначення» відмінений, а в стандарті ДСТУ ISO 9000:2009 щодо оцінювання якості немає згадки.

Якість як задоволення потреб, як корисність для клієнта доволі поширене серед вчених, задоволення потреб, проте, потреби виникають постійно, коли нема продукції чи послуги, можливості для їх задоволення у споживача, і спрямовані на усунення незадоволеності людини $[8,11]$. Ринок орієнтований 
Економічні науки: збірник наукових праць Луцького національного технічного університету. Серія "Регіональна економіка". Випуск 18 (71). Редкол.: відп. ред. д.е.н., професор Л.Л. Ковальська. Луиьк: ІВВ Луиького НТУ, 2021. 278 с.

не просто на задоволення потреб споживачів, а на задоволення платоспроможного попиту, що випливає 3 його потреб. У визначенні якості поняття потреб $є$ вихідним. Їхні характеристики повинні відповідати характеристикам якості об’єкта. Американський спеціаліст Дж. Харрінгтон підходить до цього поняття наступним чином: якість - це «задоволення очікувань споживача за ціну, яку він може собі дозволити, коли в нього виникає потреба»; висока якість - це «перевищення очікувань споживача за більш низьку ціну, ніж він планує» [9].

Категорія якість як рівень досконалості стосується успішності регіональних продуктів та послуг. Проте, для різних груп споживачів якість однієї й тієї ж продукції чи послуги буде мати свою специфіку. На нашу думку, якість доцільно розглядати $з$ двох сторін: з позиції суб'єкта господарювання, що формує такі продукти та послуги, а також з позиції туриста, що споживає їх. Турист прагне до вибору 3 пропонованого асортименту регіональних товарів та послуг, що забезпечать або перевершить його сподівання за відповідну ціну. Для суб' єкта господарювання, якість пропонованих продукції та послуг - це раціональне використання усіх наявних ресурсів в найоптимальніший спосіб з врахуванням наявних норм, правил та стандартів якості [1].

Як економічна категорія, якість пов'язана конкретними економічними показниками, такими як наприклад туристичний збір в регіонах, який свідчить про популярність туристичних пропозицій, їх атрактивність серед туристів та відповідність якості продукції та послуг регіону визначеній ціновій політиці, що також впливає на конкурентоспроможність туристичних регіонів. У свою чергу, конкурентоспроможність продукції та послуг індустрії гостинності пов'язана 3 двома основними показниками - рівнем ціни і рівнем якості продукції та послуг [3].

Таким, чином, якість продукції та послуг в регіоні $\epsilon$ економічною категорією, яка $\epsilon$ вимірною величною та відображає ступінь задоволеності потреб споживачів у вигляді 
Економічні науки: збірник наукових праць Луцького національного технічного університету. Серія "Регіональна економіка". Випуск 18 (71). Редкол.: відп. ред. д.е.н., професор Л.Л. Ковальська. Луиьк: ІВВ Луиького НТУ, 2021. 278 с.

комплексної туристичної послуги, що надається суб'єктами господарювання індустрії гостинності.

Статистичні дані щодо сплати туристичного збору у розрізі регіонів України засвідчили, що загальна сума надходжень до місцевих бюджетів у 2020 році склала близько 130 млн грн. (рис 1). Це на 34\% менше, ніж у 2019 році (понад 196 млн грн). Проте, попри карантинні обмеження, для трьох регіонів України у 2020 році характерним був значний приріст по обсягах туристичного збору. Такий приріс спостерігався у Луганській $(33,8 \%)$, Миколаївській $(7,1 \%)$ та Київській $(4,9 \%)$ областях. Трохи більше 6000 тис. грн. сплатили Харківська (6602,35 тис. грн), Закарпатська (6436,38 тис. грн) та Запорізька $(6200,46$ тис. грн) області. Близько в рейтингу за цими показниками є Івано-Франківська (5 599,17 тис. грн) та Дніпропетровська (5 592,42 тис. грн) області. На десятому місті опинилась Миколаївська область (4 648,61 тис. грн). Волинська область займає дев'ятнадцяту позицію у рейтингу (1044,63 тис. грн) [6].

Туристичний збір - це збір, що стягується 3 туристів місцевою владою 3 метою вкладання в розвиток індустрії гостинності регіону (реставрацію чи ревіталізацію пам'яток, розвиток інфраструктури, благоустрій, проведення івентивних заходів тощо) [4, 5]. Туристичний збір сплачують туристи та гості регіону, які прибувають на територію міста чи області не 3 метою відрядження.

Найбільші показники туристичного збору характерні для туристичних міст регіонів. Позитивні тенденції сплати туристичного збору характерні для міста Луцьк.

Спостерігаємо зростання доходу від туристичного збору в період 2016-2019 рр., особливо у 2017 р., так в 2016 р. він склав - 146132, грн, а у 2017 - 247826 грн, що на $69 \%$ більше ніж за попередній рік, це пояснюється тим, що саме у 2017 р. почався активний розвитку туризму в Луцьку. Проте, у 2020 році обсяг туристичного збору в місті зменшився на 73700 тис. грн, що пов' язано з карантинними обмеженнями COVID-19 [7]. 
Економічні науки: збірник наукових праць Луцького національного технічного університету. Серія "Регіональна економіка". Випуск 18 (71). Редкол.: відп. ред. д.е.н., професор Л.Л. Ковальська. Луцьк: ІВВ Луцького НТУ, 2021. 278 с.

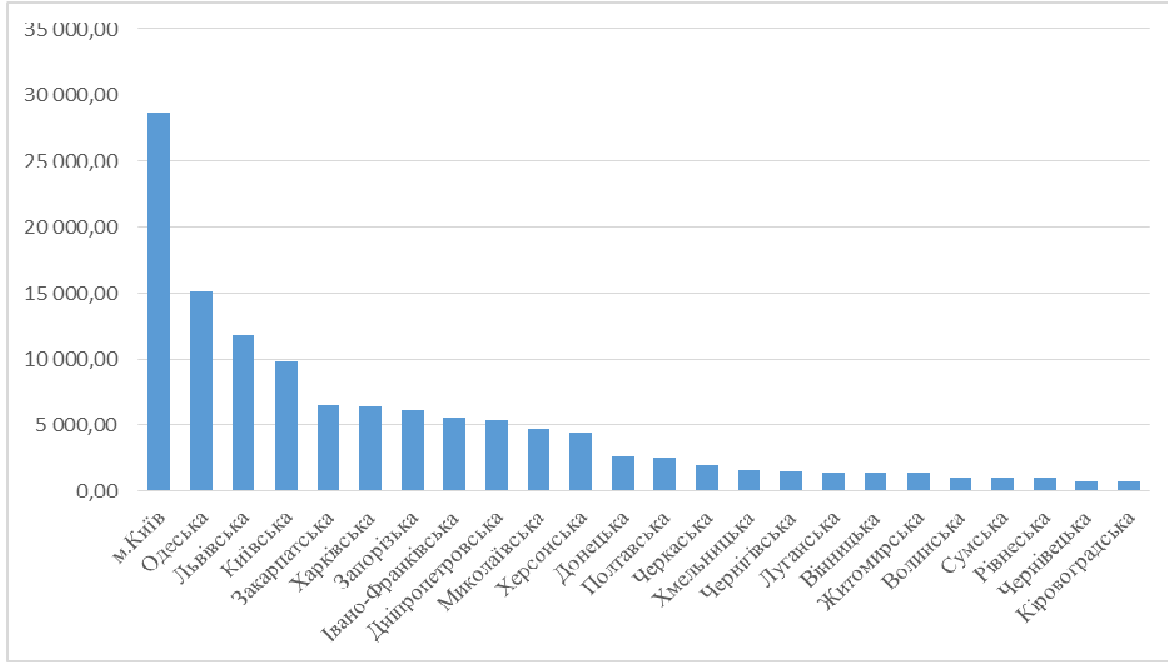

Рис. 1. Обсяги туристичного збору в регіонах України у 2020 році (тис. грн).

\section{Таблиця 1}

Обсяги туристичного збору у місті Луцьк за період 2016-2020 pp (тис. грн)

\begin{tabular}{|c|c|c|c|c|}
\hline 2016 & 2017 & 2018 & 2019 & 2020 \\
\hline 146132 & 247826 & 253808 & 587600 & 513900 \\
\hline
\end{tabular}

Луцьк характеризується відносно розвиненою інфраструктурою. У місті є достатня готельна мережа. Наявна можливість комфортно розмістити гостей міста в 17 сучасних готелях. Функціонує також ряд хостелів. У місті функціонує ряд закладів ресторанного господарства. У місті є розвинена мережа закладів культури, це 2 театри, 4 клубних заклади, 3 кінотеатри, 4 центри дозвілля, 23 музеї та 2 парки відпочинку.

Через місто проходять автомобільні шляхи загальнодержавного значення: М-08 Устилуг-Луцьк-Рівне, М-19 Доманове-Ковель-Чернівці-Мамалига. 
Економічні науки: збірник наукових праць Луцького національного технічного університету. Серія "Регіональна економіка". Випуск 18 (71). Редкол.: відп. ред. д.е.н., професор Л.Л. Ковальська. Луиьк: ІВВ Луиького НТУ, 2021. 278 с.

Про якість продукції та послуг індустрії гостинності міста свідчить асортимент івентивних заходів. Протягом року в Луцьку відбувається більше 200 різноманітних культурномистецьких подій (місцевих, всеукраїнських та міжнародних). Найпопулярнішими серед них є: фестиваль «Князівський бенкет», арт-шоу «Ніч в Луцькому замку», міжнародний фестиваль «Art Jazz Cooperation», міжнародний фестиваль українського фольклору «Берегиня», молодіжний фестиваль альтернативної музики та сучасного мистецтва «Бандерштат», міжнародний театральний фестиваль «Мандрівний вішак», Міжнародний музичний фестиваль імені Стравінського «Стравінський та Україна», Міжнародний фестиваль «Поліське літо 3 фольклором», міжнародний фестиваль «JAZZ BEZ», західний гастрономічний фестиваль «Lutsk Food Fest».

Луцьк славиться своєю історико-культурною спадщиною, у місті функціонує історико-культурний заповідник «Старий Луцьк» площею близько 41 гектар. На території заповідника розміщено 52 пам'ятки, що знаходяться під охороною держави, 3 них 39 - національного значення.

Таким чином, Луцьк має значну ресурсну базу для розвитку індустрії туризму та значний асортимент продукції та послуг для туристичного споживання.

Проте, якість туристичних послуг міста знижується через незначну кількість туристичних операторів, які формують внутрішні туристичні пропозиції. Більшість туристичних організацій, а таких на туристичному ринку міста одиниці, здебільшого обмежуються об'єктами історико-культурного заповідника «Старий Луцьк», і показують їх у всім відомому звичному ракурсі.

Для обгрунтування доцільності формування нових пропозицій продукції та послуг індустрії гостинності, які відповідають міжнародним стандартам та пошуку ефективних шляхів підвищення рівня якості досліджуваних процесів, проведемо SWOT-аналіз розвитку індустрії гостинності міста (табл. 2). 
Економічні науки: збірник наукових праць Луцького національного технічного університету. Серія "Регіональна економіка". Випуск 18 (71). Редкол.: відп. ред. д.е.н., професор Л.Л. Ковальська. Луцьк: ІВВ Луцького НТУ, 2021. 278 с.

Таблиця 2

SWOT- аналіз розвитку індустрії гостинності міста Луцьк

\begin{tabular}{|c|c|}
\hline і сторони & Слабкі сто \\
\hline $\begin{array}{l}\text { - вигідне географічне положення; } \\
\text { - достатня кількість туристичних } \\
\text { ресурсів; } \\
\text { - розвиток брендування міста; } \\
\text { - розвиток інфраструктури; } \\
\text { - прикордонне розташування; } \\
\text { - застосування п програмних } \\
\text { інструментів розвитку туризму; } \\
\text { - достатнє } \\
\text { співробітництво; транскордонне } \\
\text { - мультикультурність міста; } \\
\text { - наявність кваліфікованих кадрів. }\end{array}$ & $\begin{array}{l}\text { - незручне залізничне сполучення; } \\
\text { - недостатнє використання } \\
\text { туристичного потенціалу; } \\
\text { - конкуренція з боку сусідніх міст; } \\
\text { - незначний рівень промоції } \\
\text { туристичного потенціалу міста; } \\
\text { - недостатнє володіння іноземними } \\
\text { мовами персоналу індустрії; } \\
\text { - недостатність фінансування галузі; } \\
\text { - проблеми з благоустроєм міста; } \\
\text { - недостатній } \\
\text { туристичних пропозицій. }\end{array}$ \\
\hline
\end{tabular}

Продовження таблиці 2

\begin{tabular}{|c|c|}
\hline Можливості & Загрози \\
\hline $\begin{array}{l}\text { - наявність умов для розвитку нових } \\
\text { видів туризму; } \\
\text { - залучення інвестицій; } \\
\text { - промоція } \\
\text { потенціалу; } \\
\text { - розширення асортименту послуг; } \\
\text {-участь у грантових програмах; } \\
\text { - налагодження } \quad \text { транспортного } \\
\text { сполучення із великими містами; } \\
\text { - налагодження системи міських } \\
\text { громадських перевезень; } \\
\text { - покращення стану доріг у місті та } \\
\text { доріг обласного значення. }\end{array}$ & $\begin{array}{l}\text { - поширення пандемії; } \\
\text { - нестабільна економічна і політична } \\
\text { ситуація в Україні; } \\
\text { - зниження обсягів фінансування; } \\
\text { - популяризація виїзного туризму; } \\
\text { - зниження купівельної спроможності } \\
\text { споживачів продукції та послуг; } \\
\text { - інфляційні процеси; } \\
\text { - низький рівень культури відпочинку } \\
\text { серед населення; } \\
\text { - пасивність громади щодо розвитку. }\end{array}$ \\
\hline
\end{tabular}

Проведений аналіз засвідчив достатній ресурсний потенціал у місті для формування та надання продукції та послуг індустрії гостинності високої якості. Вважаємо за доцільне рівень якості продукції та послуг індустрії гостинності збільшити шляхом формування нових туристичних пропозицій, які б відповідали сучасним нормам, правилам та стандартам якості. Крім того, доцільно збільшити рівень промоції туристичного потенціалу міста. Пропонуємо збільшити кількість центрів туристичної інформації у місті та запровадити функціонування регіональної організації 3 менеджменту 
Економічні науки: збірник наукових праць Луцького національного технічного університету. Серія "Регіональна економіка". Випуск 18 (71). Редкол.: відп. ред. д.е.н., професор Л.Л. Ковальська. Луиьк: ІВВ Луцьького НТУ, 2021. 278 с.

туристичної дестинації «Луцьк», яка функціонуватиме на основі партнерства і взаємодії органів влади, місцевого самоврядування, господарюючих суб'єктів у сфері туризму, підприємств і об'єктів туристської інфраструктури і сфери обслуговування, громадських організацій i асоціацій, зацікавлених в якості туристичних послуг.

Висновки. Узагальнено та визначено сутність категорії «якість продукції та послуг індустрії гостинності», як економічну категорією, яка є вимірною величною та відображає ступінь задоволеності потреб споживачів у вигляді комплексної туристичної послуги, що надається суб'єктами господарювання індустрії гостинності. Визначено, що якість продукції та послуг індустрії гостинності в регіонах характеризується такими показниками як кількість туристів, кошти витрачені ними під час подорожі, час відпочинку, а також асортимент пропонованих послуг.

Проведений аналіз обсягів туристичного збору в регіонах України засвідчив, що загальна сума надходжень до місцевих бюджетів у 2020 році склала близько 130 млн грн, що на 34\% менше, ніж у 2019 році. Лідерами за цим показником $\epsilon$ Луганська (приріст 33,8\%), Миколаївська (приріст 7,1\%) та Київська (приріст 4,9\%) області.

Запропоновано підвищувати рівень якості продукції та послуг індустрії гостинності міста Луцьк шляхом: формування нових туристичних пропозицій, які б відповідали сучасним нормам, правилам та стандартам якості; підвищення рівня промоції туристичного потенціалу міста; збільшення кількості центрів туристичної інформації у місті, а також запровадження функціонування регіональних організацій 3 менеджменту туристичної дестинацій.

\section{Список бібліографічного опису}

1.Бандирська О. Якість. Розуміння, підхід, трактування. Стандартизація. Сертифікація. Якість. 2003. № 1. 54-60 с

2.Карпюк I.В. Актуальні проблеми забезпечення якості туристичних послуг в регіонах України. Актуальні проблеми економіки. 2020, випуск №5. C.83-97.

3.Матвійчук Л.Ю., Масечко І.В. Регіональний вимір рівня якості надання туристичних послуг. Економічні науки: зб. наукових праць Луцького 
Економічні науки: збірник наукових праць Луцького національного технічного університету. Серія "Регіональна економіка". Випуск 18 (71). Редкол.: відп. ред. д.е.н., професор Л.Л. Ковальська. Луцьк: ІВВ Луцького НТУ, 2021. 278 с.

національного технічного університету. Серія «Регіональна економіка». Вип. 13 (51). Редкол.: відп. ред. д.е.н., проф. Л.Л. Ковальська. Луцьк: IBВ Луцького НТУ, 2017. С. 245-253.

4.Нездоймінов С.Г., Бедрадіна Г.К. Напрями імплементації міжнародних стандартів в сфері управління якістю туристичних послуг. Innovative Approaches to Ensuring the Quality of Education, Scientific Research and Technological Processes. Monograph. Edited by Magdalena Gawron-Łapuszek, Yana Suchukova. Publishing House of University of Technology, Katowice. 2021. 1239 c. C. $1084-1089$.

5.Нездоймінов С.Г., Бедрадіна Г.К. Науково-методичні основи оцінювання якості туристичних послуг. Вісник соиіально-економічних досліджень. зб. наук. праць Одеського національного економічного університету. Одеса, 2018. Вип. 67 (3). С. 63-72.

6.Офіційний сайт Державне агентство розвитку туризму України. Режим доступу URL: https://www.tourism.gov.ua/about-dart

7.Офіційний сайт Управління туризму та промоції міста Луцької міської ради. Режим доступу URL: https://www.lutskrada.gov.ua/departments/upravlinnia-turyzmu-ta-promotsii-mista

8.Папп В.В. Організаційний механізм управління якістю послуг на туристичних підприємствах. Економіка і суспільство. Випуск 15. 2018. Режим доступу URL: http://economyandsociety.in.ua/journal-15/22-stati-15/1873-papp-vv-boshota-n-v

9.Перспективи розвитку туризму в Україні та світі: управління, технології, моделі: колект. монографія. за наук. ред. Л. Матвійчук. Луцьк: РВВ Луцького НТУ. 2019. 324 с.

10. Системи управління якістю. Основні положення та словник термінів: ДСТУ ISO 9000:2007 (ISO 9000:2005), IDT. Чинний від 2008-01-01. К: Держспоживстандарт України, 2008. 29 с. Національний стандарт України.

11. Юхновська Ю. О. Дослідження потенціалу туристичної галузі конкурентоздатних регіонів України. Держсава та регіони. Серія: Економіка та підприємництво. № 5 (110). 2019. С. 65-70.

\section{References}

1. Bandirskaya O. (2003) Quality. Understanding, approach, interpretation. Standardization. Certification. Quality. № 1. 54-60 p.

2. Karpyuk I. (2020) Current problems of ensuring the quality of tourist services in the regions of Ukraine. Current economic problems. Issue №5. P.83-97.

3. Matviychuk L., Masechko I. (2017) Regional measurement of the level of quality of tourist services. Economic sciences: coll. scientific works of Lutsk National Technical University. Regional Economy Series. Issue 13 (51). S. 245-253.

4. Nezdoiminov S., Bedradina G. (2021) Directions of implementation of international standards in the field of quality management of tourist services. Innovative Approaches to Ensuring the Quality of Education, Scientific Research and Technological Processes. Monograph. Edited by Magdalena Gawron-Łapuszek, 
Економічні науки: збірник наукових праць Луцького національного технічного університету. Серія "Регіональна економіка". Випуск 18 (71). Редкол.: відп. ред. д.е.н., професор Л.Л. Ковальська. Луцьк: ІВВ Луцького НТУ, 2021. 278 с.

Yana Suchukova. Publishing House of the University of Technology, Katowice. 1239 p. Pp. 1084-1089.

5. Nezdoiminov S., Bedradina G. (2018) Scientific and methodological bases of assessing the quality of tourist services. Bulletin of socio-economic research. collection. Science. Works, Odessa National Economic University. Odessa. Issue 67 (3). Pp. 63-72.

6. Official site of the State Agency for Tourism Development of Ukraine. Access mode URL: https://www.tourism.gov.ua/about-dart

7. Official site of the Department of Tourism and Promotion of the city of Lutsk City Council. Access mode URL: https://www.lutskrada.gov.ua/departments/upravlinnia-turyzmu-ta-promotsii-mista

8. Papp V. Organizational mechanism of quality management of services at tourist enterprises. Economy and society. Issue 15. 2018. Access mode URL: http://economyandsociety.in.ua/journal-15/22-stati-15/1873-papp-v-v-boshota-n-v

9. Prospects for tourism development in Ukraine and the world: management, technology, models. Collect. Monograph (2019) According to the scientific edition L. Matviychuk. Lutsk: ED Lutsk NTU. 324 p.

10. Quality management systems. Basic provisions and glossary of terms: DSTU ISO 9000: 2007 (ISO 9000: 2005), IDT. Valid from 2008-01-01. K: Derzhspozhyvstandart Ukrainy, 2008. 29 p. National standard of Ukraine.

11. Yukhnovska Y. (2019) Research of the potential of the tourism industry of competitive regions of Ukraine. State and regions. Series: Economics and Entrepreneurship. № 5 (110). S. 65-70.

DOI: https://doi.org/10.36910/2707-6296-2021-18(71)-13

УДК 339.138:330.341.1

Морохова В.О., к.е.н., професор

Бойко О.В., к.е.н., доцент

Лорві І.Ф., к.е.н., доцент

Луцький національний технічний університет

\section{МАРКЕТИНГ ІННОВАЦІЙ ЯК КОМПЛЕКСНИЙ ІНСТРУМЕНТ ДОСЯГНЕННЯ СТРАТЕГІЧНИХ ЦІЛЕЙ ПІДПРИЄМСТВА В УМОВАХ КОНКУРЕНТНОГО СЕРЕДОВИЩА}

У статті розглянуто питання маркетингового забезпечення інноваційної діяльності підприємств на засадах побудови ефективної системи маркетингу 